\title{
NILAI KARAKTER DALAM NOVEL BIOGRAFI HATTA: AKU DATANG KARENA SEJARAH KARYA SERGIUS SUTANTO
}

\author{
Anwar Efendi \\ Universitas Negeri Yogyakarta \\ email: anwar@uny.ac.id
}

\begin{abstract}
Abstrak
Penelitian ini bertujuan mendeskripsikan wujud dan pengekspresian nilainilai karakter dalam novel biografi Hatta Aku Datang Karena Sejarah Karya Sergius Sutanto. Pengumpulan data menggunakan teknik studi dokumentasi atau kajian pustaka. Analisis data dilakukan dengan langkah-langkah sebagai berikut. Pertama, membaca untuk menyeleksi dan menandainya kata, frasa, kalimat, paragraf, dan wacana yang mengandung informasi berkaitan dengan nilai-nilai karakter. Kedua, mengidentifikasi dan mengklasifikasikan data berdasarkan butirbutir masalah yang telah dirumuskan, tidak melihat bagian per bagian. Ketiga, menafsirkan kembali secara semiotik seluruh data teridentifikasi dan terklasifikasi untuk menemukan kepaduan, kesatuan, dan hubungan antardata. Hasil penelitian sebagai berikut. Pertama, nilai-nilai karakter utama, yakni (a) kemandirian, (b) semangat kebangsaan, (c) cinta tanah air, (d) cinta damai, (e) gemar membaca, dan (f) kejujuran. Kedua, pengekspresian nilai-nilai karakter disajikan dengan dua pola, yaitu (a) penyampaian langsung dengan cara pendeskripsian karakter, tindakan, dan perilaku tokoh oleh pengarang (pencerita); dan (b) penyampaian tidak langsung dengan cara paparan sikap dan tingkah laku tokoh menghadapi peristiwa dan konflik.
\end{abstract}

Kata kunci: novel biografi, nilai karakter, pola perilaku, realitas kehidupan

\section{CHARACTER VALUES IN THE BIOGRAPHICAL NOVEL HATTA: AKU DATANG KARENA SEJARAH BY SERGIUS SUTANTO}

Abstract: This study aims to describe the form and expression of character values in Hatta: Aku Datang Karena Sejarah, a biograpical novel by Sergius Sutanto. The data collection technique was documentation study or literature review. The data analysis consisted of the following steps: first, reading to select and mark words, phrases, sentences, paragraphs, and discourses that contain information related to character values; second, identifying and classifying data based on the problem points formulated, not seeing part by part; third, semiotically reinterpreting all data identified and classified to find cohesion, unity, and relationships between data. The results of the study are as follows. First, the values of the main character include (a) independence, (b) national spirit, (c) patriotism, (d) love for peace, (e) a fondness for reading, and (f) honesty. Second, the expression of character values is presented in two patterns, namely (a) direct delivery by describing the character, actions, and behavior of the character by the author (narrator); and (b) indirect delivery by way of exposure to attitudes and behaviors of the character in facing events and conflicts.

Keywords: biographical novel, character values, behavior patterns, reality of life 


\section{PENDAHULUAN}

Kleden

(2004:106)

menyebutkan ada tiga kegelisahan yang dialami pengarang (sastrawan) dalam proses menciptakan karya sastra. Pertama, kegelisahan metafisik, yakni hubungan manusia dengan sang pencipta. Kedua, kegelisahan sosial, yang mencerminkan hubungan antara manusia dan manusia lainya dalam struktur sosial. Ketiga, kegelisahan eksistensial, yang menggambarkan usaha menghadapi dan mencoba menyelesaikan persoalan diri sendiri.

Salah satu wujud karya sastra yang muncul karena adanya kegelisahan individual adalah karya sastra dalam bentuk novel biografi. Novel biografi berisi fakta historis tentang perjalanan hidup seseorang yang disajikan dalam naratif imajinatif. Harapannya, dengan membaca novel biografi, tidak hanya bertemu dengan kumpulan informasi berupa data dan fakta, tetapi memperoleh tawarantawaran pemikiran alternatif dalam kerangka permasalahan kehidupan yang lebih luas (Khofiyana, Suyitno, \& Saddhono, 2013).

Dalam novel biografi, rekam jejak seseorang tidak disajikan dalam bentuk paparan nasehat dan petuah yang bersifat menggurui dan tendensius. Rekaman jejak tersebut disajikan dalam paparan yang kontemplatif sehingga pembaca memperoleh pencerahan yang sublimatif dan bersifat individual. Artinya, dengan membaca novel biografi yang sama, dimungkinkan setiap orang memperoleh pengalaman dan pengetahuan berbeda yang bersumber dari tokoh yang dihadirkan dalam novel biografi tersebut (Hasan, 2002).
Biografi dalam bahasa Inggris biography atau biographie (Perancis), berarti kisah tentang hidup seseorang yang ditulis orang lain (Abrams, 2000). Kisah hidup ini dapat berupa tulisan hasil telaah ilmiah atau dalam bentuk karya sastra yang melukiskan riwayat hidup seseorang. Biografi dapat memberi informasi mengenai perkembangan pribadi maupun karya serta perjalanan hidup seseorang. Bila data-datanya semata-mata berdasarkan sumber-sumber yang bersifat faktual, berupa fakta-fakta, maka biografi itu bersifat ilmiah. Sementara itu, bila ada unsur-unsur rekaan dalam penulisannya, maka disebut biografi dalam bentuk roman (Nurgiyantoro, 2015).

Dalam khasanah perkembangan sastra Indonesia, biografi yang ditulis dalam bentuk novel (roman) sudah ada sejak lama. Salah satu penulis roman biografi adalah sastrawan HAMKA. HAMKA menulis biografi berjudul Ayahku yang berisikan kisah hidup ayahandanya, yaitu Haji Abdul Karim Amrullah dalam bentuk naratif (novel). Pengarang lain yang menulis roman biografi, yaitu NH Dini, terkenal dengan cerita kenangannya: Sebuah Lorong di Kotaku, Padang Ilalang di Belakang Rumah, Langit dan Bumi Sahabat Kami, dan Sekayu. Beberapa tahun lalu muncul novel fenomenal yang juga ditulis berdasarkan kisah hidup penulisnya, yaitu Laskar Pelangi (Andrea Hirata). Akhir-akhir ini banyak muncul biografi para tokoh-tokoh bangsa yang ditulis dalam format novel. Beberapa contoh di antaranya: Penakluk Badai (Hasyim Asyari), Jejak Sang Pencerah (Ahmad Dahlan), Api Republik (Hamengku Buwono IX), Kuantar ke Gerbang (Soekarno), Aku Datang Karena Sejarah (Mohammad 
Hatta), Habibie dan Ainun (BJ Habibie), dan Peci Miring (Gus Dur).

Salah satu novel biografi yang menarik adalah biografi sosok tokoh bangsa Mohammad Hatta. Sejarah kehidupan Bung Hatta menarik dikaji dan diteladani, utamanya bagi generasi muda saat ini dan untuk masa-masa mendatang. Ketokohan Bung Hatta tampak menonojol sejak sebagai pemuda Indonesia yang belajar di Belanda, memimpin perjuangan dalam pergerakan kebangsaan untuk kemerdekaan Indonesia saat berada di negeri penjajah. Kiprahnya berlanjut dalam memperjuangkan kemerdekaan Indonesia, pernah diasingkan dan dibuang di Boven Digoel dan Banda Neira, sampai berujung pada perannya dalam proklamasi kemerdekaan Republik Indonesia, 17 Agustus 1945. Keteguhannya pada prinsip kebenaran, keadilan, dan kemanusiaan, mendasari Bung Hatta mengambil keputusan yang besar dan fenomenal, dengan mengundurkan diri sebagai Wakil Presiden, pada 1 Desember 1956. Selanjutnya, Bung Hatta menjalani kehidupan sebagai rakyat biasa, dengan penuh liku, pahit getir, dan suka duka sampai wafat pada 14 Maret 1980.

Penelitian ini bertujuan mendeskripsikan nilai-nilai karakter apa saja dan bagaimanakah cara pengekpresian nilai-niai karakter dalam novel biografi yang berjudul Hatta: Datang Karena Sejarah. Hadirnya sosok Mohammad Hatta dalam bentuk novel biografi tentu akan membawa pesan berbeda dibandingkan dengan narasi dalam bentuk sejarah yang bersifat faktual.

\section{METODE}

Sumber data penelitian adalah novel biografi tokoh Mohammad Hatta, yang berjudul Hatta: Aku Datang Karena Sejarah karya Sergius Sutanto. Mohammad Hatta adalah salah satu sosok penting dalam sejarah perjalanan bangsa Indonesia. Kejujuran dan kesederhanaan tokoh Mohammad Hatta sangat kuat tertanam dan terpatri dalam setiap hati dan pikiran masyarakat dan bangsa Indonesia

Pengumpulan data menggunakan teknik studi dokumentasi atau kajian pustaka. Teknik ini digunakan karena sumber data bersifat fenomenologis dan idiografis, yakni paparan teks verbal dalam karya sastra. Kegiatan pengumpulan data dilaksanakan dengan langkah-langkah berikut. Pertama, dengan bekal pengetahuan dan wawasan yang dimiliki, peneliti membaca dengan cermat dan teliti seluruh sumber data. Dalam melakukan pembacaan sumber data, peneliti mendasarkan pada sikap kritis, kecermatan, dan ketelitian sehingga dapat menghayati dan memahami arti secara mendalam, memadai, dan mencukupi (prinsip verstehen dan erlebnis). Kedua, setelah menyelesaikan kegiatan pertama, peneliti membaca sekali lagi sumber data untuk memberi tanda bagian-bagian tertentu yang akan diangkat menjadi data dengan pemberian kode sesuai dengan fokus masalah. Langkah kedua dilanjutkan dengan kegiatan pencatatan data terpilih yang akan dianalisis.

Kegiatan analisis data dilakukan dengan langkah-langkah sebagai berikut. Pertama, membaca untuk menghayati dan memahami seluruh sumber data penelitian, kemudian menyeleksi dan menandainya kata, frasa, kalimat, paragraf, dan wacana 
yang mengandung informasi berkaitan dengan nilai-nilai karakter. Kedua, mengidentifikasi dan mengklasifikasikan seluruh data secara utuh dan menyeluruh berdasarkan butirbutir masalah yang telah dirumuskan, tidak melihat bagian per bagian. Identifikasi dan klasifikasi data berkaitan dengan fokus penelitian, yakni wujud dan pola pengekspresian nilai-nilai karakter. Ketiga, menafsirkan kembali secara semiotik seluruh data teridentifikasi dan terklasifikasi untuk menemukan kepaduan, kesatuan, dan hubungan antardata.

Keabsahan data diperiksa dengan dua cara. Pertama, keabsahan data diperiksa dengan cara membaca dan menelaah berkali-kali sumber data penelitian agar diperoleh penghayatan dan pemahaman arti yang memadai dan mencukupi. Kedua, keabsahan data diperiksa dengan cara mengecek kepada sejawat. Penilaian sejawat dilakukan dengan cara berdiskusi dan bertukar pikiran tentang fokus permasalahan penelitian dengan teman sejawat yang dianggap memiliki kompetensi berkaitan dengan fokus penelitian.

\section{HASIL DAN PEMBAHASAN}

\section{Hasil Penelitian}

Secara teoretik, $\begin{array}{r}\text { banyak } \\ \text { nilai-nilai }\end{array}$
kumusan dan kategori para ahli.
karakter yang dikemukan para satu ahli pendidikan karakter,
Salah
Lickona (1993) menyebutkan adanya
sepuluh jenis karkater, yakni:
trustworthiness,
responsibility, fairness, caring,
honesty, courage, diligence, integrity,
dan citizenship. Dalam rangka lebih
memperkuat pelaksanaan pendidikan

karakter, telah teridentifikasi 18 nilai yang bersumber dari agama, Pancasila, budaya, dan tujuan pendidikan nasional, yaitu: religius, jujur, toleransi, disiplin, kerja keras, kreatif, mandiri, demokratis, rasa ingin tahu, semangat kebangsaan, cinta tanah air, menghargai prestasi, bersahabat/ komunikatif, cinta damai, gemar membaca, peduli lingkungan, peduli sosial, dan tanggung jawab (Kemendiknas, 2010).

Dalam penelitian ini, nilai karakter yang diungkapkan adalah nilai karakter utama yang melekat pada sosok tokoh Muhammad Hatta yang diekspresikan dalam novel birografi. Sesuai dengan fokus masalah yang dikaji, hasil penelitian mencakup dua hal, yaitu (a) nilai-nilai karakter dan (b) cara pengekspresian nilai karakter dalam novel biografi. Secara terperinci hasil penelitian disajikan pada Tabel 1 dan 2 . 
Tabel 1 Wujud Nilai Karakter dalam Novel Biografi Mohammad Hatta

\begin{tabular}{|c|c|c|}
\hline No & Nilai Karakter & Deskripsi \\
\hline 1 & Mandiri & $\begin{array}{l}\text { Sejak kecil tinggal terpisah dari orang tua untuk } \\
\text { menempuh Pendidikan }\end{array}$ \\
\hline 2. & $\begin{array}{l}\text { Semangat Kebangsaan } \\
\text { (Nasionalisme) }\end{array}$ & $\begin{array}{l}\text { Terlibat aktif dalam pergerakan dan perjuangan merebut } \\
\text { kemerdekaan negara Indonesia }\end{array}$ \\
\hline 3 & Cinta tanah air & $\begin{array}{l}\text { Memutuskan kembali ke tanah air meskipun ada } \\
\text { kesempatan yang lebih bagus di luar negeri }\end{array}$ \\
\hline 4 & Cinta Damai & $\begin{array}{l}\text { Menjaga dan memelihara persahabatan dengan pihak atau } \\
\text { orang yang memusuhi dan membenci }\end{array}$ \\
\hline 5 & Gemar Membaca & $\begin{array}{l}\text { Menjadikan buku sebagai bagian penting dalam sejarah } \\
\text { perjalanan hidup }\end{array}$ \\
\hline 6. & Kejujuran & $\begin{array}{l}\text { Sikap dan perilaku yang menceminkan kesatuan antara } \\
\text { pengetahuan, perkataan, dan perbuatan sebagai pribadi } \\
\text { yang dapat dipercaya }\end{array}$ \\
\hline
\end{tabular}

Tabel 2 Pola Pengekspresian Nilai Karakter dalam Novel Biografi Mohammad Hatta

\begin{tabular}{clll}
\hline No & \multicolumn{1}{c}{ Pola } & & \multicolumn{2}{c}{ Indikator } \\
\hline 1 & Penyampaian & a. & deskripsi langsung pengarang tentang karakter tokoh \\
& Langsung & b. & deskripsi pengarang tentang perilaku dan tindakan tokoh \\
2. & $\begin{array}{l}\text { Penyampaian Tidak } \\
\text { Langsung }\end{array}$ & a. & paparan peristiwa dan konflik yang dialami tokoh \\
& b. & paparan sikap dan tingkah laku tokoh menghadapi \\
& & \multicolumn{2}{c}{ peristiwa dan konflik } \\
\hline
\end{tabular}

Kajian nilai karakter yang terdapat dalam karya sastra, termasuk novel biografi, penting dilakukan sebagai salah satu upaya untuk pengembangan dan pembinaan karakter, khususnya bagi generasi muda. Kegiatan pembinaan dan pengembangan karakter salah satunya dilakukan melalui kegiatan pembelajaran di sekolah (Youpika \& Zuchdi, 2016).

\section{PEMBAHASAN}

\section{Nilai Karakter dalam Novel Biografi Mohammad Hatta \\ Karakter Kemandirian}

Kemandirian adalah sikap
(perilaku) dan mental yang
memungkinkan seseorang untuk
bertindak bebas, benar, dan bermanfaat.
Seseorang yang berusaha melakukan
segala sesuatu dengan jujur dan benar
atas dorongan dirinya sendiri dan

kemampuan mengatur diri sendiri, sesuai dengan hak dan kewajibannya, sehingga dapat menyelesaikan masalah-masalah yang dihadapinya; serta bertanggung jawab terhadap segala keputusan yang telah diambilnya melalui berbagai pertimbangan sebelumnya (Kemendiknas, 2011).

Mandiri adalah keadaan yang dapat berdiri sendiri, tidak tergantung pada orang lain. Ciri-ciri kemandirian, antara lain: (a) memiliki kemampuan untuk selalu berusaha berinisiatif dalam segala hal, (b) memiliki kemampuan mengerjakan tugas yang dibebankan padanya, (c) memperoleh kepuasan dari kegiatan yang dikerjakan, (d) memiliki kemampuan mengatasi rintangan yang dihadapinya dalam mencapai kesuksesan, (e) memiliki kemampuan untuk selalu bertindak jujur dan benar sesuai hak dan kewajibannya, (f) 
memiliki keinginan untuk membantu orang lain atau melakukan tindakan yang bermanfaat bagi orang lain dan lingkungannya, (g) memiliki kemampuan berpikir secara kritis, kreatif dan inovatif terhadap sesuatu yang dikerjakannya atau diputuskannya, baik dalam segi manfaat atau keuntungannya, maupun segi negatif dan kerugian yang akan dialaminya, dan (h) tidak merasa rendah diri jika harus berbeda pendapat dengan orang lain, berani mengemukakan pendapatnya walaupun berbeda, dan mampu menerima pendapat yang lebih benar (Smit, 2002).

Karakter mandiri dalam diri Hatta sudah tampak semenjak kecil. Dalam pikiran Hatta semasa kecil muncul keinginan yang kuat untuk bisa pergi ke Mekkah dan melanjutkan studi ke Universitas Al-Azhar di Kairo. Jika diberi lima pilihan: rendang, laut, buku, sekolah, dan Makkah. Maka dengan cepat dia akan pilih yang terakhir Makkah. Itulah pilihan Hatta kecil, sebelum dia mengenal sekolah. (hlm 27).

Setelah lulus dari Sekolah Rakyat di Bukit Tinggi, Hatta berkeinginan kuat untuk melanjutkan pendidikannya. Untuk itu, ia harus pergi dan pindah ke Kota Padang dan harus hidup secara mandiri jauh dari orang tua dan kerabat.
Akhirnya, Hatta menunda keberangkatannya ke Betawi dan memilih masuk MULO di Padang. Di Padang, kemandirian Hatta muda mulai terbentuk. Dia mulai belajar mengurus diri, membagi waktu antara sekolah dan berorganisasi. Wawasannya pun mulai merebak dengan mulai mengenal beberapa cendekiawan Muslim yang banyak memberi inspirasi di kota itu (hlm 66).

Setelah menyelesaikan MULO empat tahun di Padang, Hatta melanjutkan studi di Prins Hendrik School (PHS) sebuah sekolah menengah dagang yang ada di Betawi (Jakarta). Kehidupan selama di Betawi tentu saja menuntut jiwa kemandirian yang semakin tinggi. Tuntutan kemandirian itu semakin meningkat saat ia memutuskan untuk melanjutkan studi ke Negeri Belanda. Hatta dituntut untuk bisa hidup dan menghidupi dirinya selama belajar di Negeri Belanda.

"Tiba di Belanda, Hatta masuk Handels Hoge School di Rotterdam. Selang beberapa bulan kemudian, dia mulai berkenalan dengan Indische Vereeniging lewat kawan-kawan yang bermukim di Leiden. Hatta mulai rajin menulis di majalah perhimpunan dan koran-koran terbitan Belanda dan Batavia. Sebagian honornya bisa menambah beasiswa yang didapatnya dari Pemerintah Belanda lewat Mr. Joekes (hlm 90).

Karakter kemandirian dalam diri tokoh Hatta sangat bernilai dan inspiratif mengingat kondisi dan keadaan zaman pada masa itu. Sarana dan fasilitas transportasi dan komunikasi pada masa itu tentu saja tidak selengkap, semudah, dan semurah saat itu. Artinya, memerlukan jiwa kemandirian dan bahkan keberanian yang luar biasa, karena tokoh tersebut harus menempuh perjalanan yang panjang, waktu yang lama, dan transportasi yang sulit. Pada titik inilah, generasi muda saat ini yang notabene telah dilimpahi kemudahan dan kecepatan dalam segala aspek, harus belajar dan mencontoh sikap kemandirian tokoh Hatta, utama dalam 
proses menempuh jenjang pendidikan. Masa remaja sebagai masa transisi menuju dewasa memerlukan sikap kemandirian agar tidak mengalami krisis identitas (Rostiyati, Khuzaemah, \& Mulyaningsi, 2019).

\section{Karakter Semangat Kebangsaan}

Semangat kebangsaan atau nasionalisme adalah sikap dan tindakan yang menempatkan kepentingan bangsa dan negara di atas kepentingan pribadi dan golongan (Kemendiknas, 2011). Nasionalisme mengikat warga negara untuk; (a) memiliki kesadaran sebagai satu bangsa, yang dapat memperkuat rasa kebangsaan, persatuan, dan kesatuan; (b) jiwa, semangat, dan nilai-nilai patriotik yang berkaitan dengan perasaan cinta tanah air, cinta kepada tanah tumpah darah, cinta kepada negara dan bangsa, cinta kepada milik budaya bangsa sendiri, kerelaan untuk membela tanah airnya; (c) jiwa, semangat, dan nilai-nilai kreatif dan inovatif; dan (d) jiwa, semangat, dan nilai-nilai yang mampu membentuk kepribadian, watak, dan budi luhur bangsa (Mustopo, 1983). Semangat kebangsaan atau nasionalisme merupakan salah satu nilai karakter utama dalam mata pelajaran Pendidikan Kewarganegaraan (Azizah \& Marzuki, 2018).

Dalam sejarah perjalanan bangsa Indonesia, nasionalisme tidak dapat dipisahkan dari imperialisme dan kolonialisme Belanda, karena nasionalisme merupakan rekasi terhadap bentuk kolonialisme. Hubungan antara keduanya dapat dilihat dalam dua tataran, yaitu tataran universal dan tataran kontekstual. Dalam tataran universal, nasionalisme adalah gerakan emasipasi, keinginan mendapatkan atau membangun kembali dunia yang bebas untuk merealisasikan dirinya sebagai subjek yang mandiri dan bebas. Dalam tataran kontekstual, nasionalisme merupakan kehendak untuk membangun sebuah dunia yang dapat merealisasikan dirinya secara bebas. (Refly, 1993).

Semangat kebangsaan dalam diri tokoh Hatta tampak menonjol pada beberapa bulan kemudian setelah Hatta sampai di Belanda. Hatta turut terlibat aktif dalam kegiatan Perhimpoenan Indonesia. Bahkan, Hatta sempat menjadi Ketua Perhimpoenan Indonesia, pada tahun 1926, meneruskan kepemimpinan Iwan Koseoema Soemantri, Nazir Pamoentjak, dan Soekiman Wirjosandjojo.

"Begitu dikukuhkan sebagai Ketua Perhimpoenan Indonesia, pada 17 Januari 1926, Hatta langsung menggencarkan aksi propaganda luar negeri dalam bidang politik. Tujuannya tak lain untuk memperkenalkan nama "Indonesia" kepada dunia Internasional. Februari 1927, Hatta juga hadir pada sebuah kongres yang cukup penting di abad 20, "Kongres Menentang Imperialisme dan Penindasan Kolonial", di Brussel, Belgia. Sebuah kongres internasional yang tidak saja telah menaikkan pamor nama "Indonesia", tapi juga telah membuka cakrawala pergaulan di pentas politik dunia (hlm 101).

Gagasan semangat kebangsaan (nasionalisme) dalam diri Hatta juga dituangkan dalam sebuah tulisan yang berjudul "Indonesia di tengah-tengah revolusi Asia", dimuat dalam buku Gedenkboek. Buku itu khusus diterbitkan dalam rangka memperingati 
ulang tahun Perhimpoenan Indonesia kelima belas (1908 - 1913). Terbitnya buku Gedenkboek diharapkan dapat membuka telinga pemerintah Hindia untuk mendengarkan suara perjuangan rakyat Indonesia.

"Indonesia di tengah-tengah revolusi Asia," Nazir mengeja judul karangan. Hatta diam memperhatikan. "Tajam," kata Nazir. "Terima kasih Bung. Aku mendapatkan referensinya dari beberapa buku mengenai sejarah dan perjuangan Asia yang kubeli sewaktu ke Paris tempo hari," kata Hatta menjelaskan. "Dari sejarah Turki, aku mendapatkan contoh-contoh tentang 'berjuang atas kesanggupan tenaga sendiri', dan dari perjuangan India aku mengambil pengaruh dan kekuatan non-cooperation" (hlm 92).

Puncak semangat kebangsaan dalam diri Hatta saat ia dengan dua rekannya, Nazir Pamontjak dan Ali Sastroamidjojo, ditangkap dan ditahan oleh Pemerintah Belanda. Hatta dan kawan-kawan dituduh menjadi anggota perhimpunan terlarang, terlibat dalam pemberontakan, dan penghasutan untuk menentang Kerajaan Belanda. Tentu saja tuduhan-tuduhan itu bagian dari rekayasa Pemerintah Belanda yang merasa terganggu dengan pemikiran dan gerakan Hatta dan kawan-kawan seperjuangan melalui wadah Perhimpoenan Indonesia. Hal utama yang diperjuangkan adalah kemerdekaan tanah air Indonesia.

"Lewat sidang yang alot, tiga tahap, masing-masing 8 Maret, 9 Maret, dan berakhir pada sidang 22 Mare 1928, dengan keputusan yang mengharu biru, Hatta, Nazir Pamontjak, Ali Sastroamidjojo, dan Abdul Madjid
Djojoadiningrat dinyatakan bebas dari segala tuduhan. Kami bukan pemberontak, kami adalah pejuang (hlm 154).

Sosok tokoh Hatta sudah tidak diragukan lagi kekuatan karakter semangat kebangsaan atau nasionalisme dalam diri pribadinya. Dengan kemampuan, posisi, dan situasi yang dihadapi, Hatta terlibat dalam sejarah perjuangan bangsa, sehingga menjadikan Indonesi sebagai negara yang merdekan dan bermartabat.

\section{Karakter Cinta Tanah Air}

Cinta tanah air yakni sikap dan perilaku yang mencerminkan rasa bangga, setia, peduli dan penghargaan yang tinggi terhadap bahasa, budaya, ekomoni, politik dan sebagainya, sehingga tidak mudah menerima tawaran bangsa lain yang dapat merugikan bangsa sendiri (Kemendiknas, 2011). Rasa cinta tanah air adalah rasa kebanggaan, rasa memiliki, rasa menghargai, rasa menghormati dan loyalitas yang dimiliki oleh setiap individu pada negaranya. Hal itu tercermin dari perilaku membela tanah air, menjaga dan melindungi tanah air, rela berkorban demi kepentingan bangsa dan negaranya, mencintai adat atau budaya dengan melestarikannya dan melestarikan alam dan lingkungan.

Dalam cinta tanah air terdapat nilai-nilai kepahlawanan, yaitu rela dengan sepenuh hati berkorban untuk bangsa dan negara. Ciri-ciri cinta tanah air di antaranya; (a) rela berkorban untuk tanah air dan bangsa; bangga berbangsa, berbahasa, dan bertanah air Indonesia; (b) giat dalam melaksanakan pembangunan di segala bidang; dan (c) ikut mempertahankan persatuan dan 
kesatuan.

Karakter cinta tanah air pada sosok Hata ditunjukkan dengan pilihannya untuk pulang ke Indonesia selesai menempuh pendidikan di Belanda. Dia memilih meneruskan kerasnya perjuangan untuk mewujudkan kemerdekaan Indonesia.

Sesudah melewati berbagai romantika perjuangan di Negeri Belanda, Hatta kembali ke Indonesia. Sesungguhnya kalau mau, tokoh kelahiran Bukit Tinggi ini bisa hidup senang di Hindia Belanda karena dengan ilmu yang dimilikinya ia dapat mengabdi pada Pemerintah Kolonial Belanda. Tetapi Hatta tidak memilih berjalan "di bawah sinar rembulan". Ia tetap terus berjuang untuk kemerdekaan tanah airnya.

Perilaku cinta tanah air dapat diwujudkan dalam berbagai bentuk, di antaranya memelihara persatuan dan kesatuan dan menyumbangkan pengetahuan dan keterampilan yang dimiliki untuk membangun negara. Generasi muda dapat menuntut ilmu dari manapun dan setinggi apapun, kemudian dimanfaatkan sebesarbesarnya untuk kemajuan pembangunan di tanah air Indonesia.

\section{Karakter Cinta Damai}

Karakter cinta damai adalah sikap dan tindakan yang mendorong seseorang untuk menghasilkan sesuatu yang berguna bagi masyarakat, dan mengakui, serta menghormati keberhasilan orang lain. Cinta damai merupakan sikap dan tindakan seseorang untuk menjaga kedamaian, kerukunan, dan keharmonisan dalam kehidupan bermasyarakat, berbangsa maupun benegara (Kemendiknas, 2011).
Cinta damai adalah sikap, perkataan, dan tindakan yang menyebabkan orang lain merasa senang dan aman atas kehadiran dirinya. Beberapa ciri atau karakteristik pribadi cinta damai, antara lain: (a) ramah terhadap orang lain, (b) mau berteman dengan siapapun, (c) mengucapkan salam atau selamat ketika bertemu teman untuk pertama kalinya, (d) tidak suka mengejek, (e) berkata sopan dengan siapapun, (f) menghargai perbedaan, $(\mathrm{g})$ tidak mencela orang lain yang berbeda pendapat dalam kehidupan sehari-hari, (h) mau bekerjasama dengan teman yang berbeda gender ataupun berbeda latar belakang sosial, ekonomi, budaya dan agama, (i) merasa bertanggung jawab atas keselamatan dan keamanan teman, (j) menciptakan suasana harmonis di lingkungan dimanapun mereka berada, dan (k) tidak membicarakan kekurangan orang lain di depan umum (Smit, 2002).

Karakter cinta damai yang menonjol adalah sikap damai dan keikhlasan sosok Muhammad Hatta terhadap tindakan yang pernah dilakukan Presiden Soekarno. Dalam catatan sejarah ada beberapa peristiwa yang menjadikan Dwi Tunggal (Soekarno - Hatta) yang akhirnya harus berpisah jalan karena perbedaan prinsip. Puncaknya, Muhamad Hatta mengundurkan diri sebagai Wakil Presiden. Tampaknya, pilihan sikap Hatta itu membawa konsekuensi, antara lain: harus pindah dari rumah dinas dan tinggal di rumah yang sederhana dengan tanggungan biaya pribadi dan bertarif mahal. Bahkan, Hatta pernah dilarang (diberhentikan secara sepihak) sebagai dosen di UGM.

Sikap cinta damai dan persahabatan ditunjukkan Hatta di 
masa-masa akhir kehidupan Presiden Soekarno. Sejarah membuktikan bahwa Soekarno juga mengalami nasib yang tragis, tersingkir dari puncak kejayaan sebagai presiden, ketika tampuk pimpinan beralih ke tangan Presiden Soeharto. Soekarno harus hidup tersiolasi dari dunia luar, tinggal di Wisma Yarso, dalam kondisi sakit secara psikis dan fisik.

Soekarno kritis. Hatta melangkah cepat menyusuri lorong RSPAD Gatot Soebroto, Jakarta. Sudah tiga hari Soekarno dipindahkan ke RSPAD dari kerangkengnya di Wisma Yarso setelah diberitakan koma pada malam 16 Juni 1970. Pandangan mata Hatta lurus ke depan. Bayangan Soekarno sekelebat muncul di benaknya. Lama sudah dia tidak berhubungan dengan sahabatnya itu. Soekarno jarang menggubris surat-surat yang dilayangkan. Kritik, saran, dan keluh kesah Hatta terhadap Demokrasi Terpimpin seakan daun-daun beringin kering di halaman belakang istana. Astaghfirullah, Hatta mengucap pelan, nyaris tak terdengar. Dia kaget dengan penglihatannya. Benarkah ini Soekarno? Sejenak Hatta seperti tidak mengenalinya. Ada apa dengan kau, No? batin Hatta. Sebentuk wajah yang membengkak dengan lubanglubang kecil di permukaannya. Bibir terkatup, tebal, dan kering. Rambut di kepala pun sudah sangat tipis. Mengapa cepat sekali berubah? Tanyanya dalam hati. Hatta terpaku (halaman, 352)

Kamar di RSPAD Gatot Soebroto menjadi saksi bisu, dua sosok yang dulu sangat dikenal dengan sebutan Dwi Tunggal. Dua orang sahabat senasib seperjuangan yang berhasil memproklamasikan kemerdekaan Indonesia. Itulah satu babak terpenting dalam hidup Hatta, saat ia harus mengurai kembali sejarah lukanya sekaligus menutupnya dengan sebuah kata maaf untuk sahabatnya, Soekarno. Hatta menyadari bahwa seringkali penderitaan berubah menjadi sebuah keberanian untuk terus hidup dan memaafkan. Fakta sejarah membuktikan, dua hari setelah Hatta menjenguk di RSPAD, tanggal 21 Juni 1970, Soekarno meninggal dunia.

Sikap cinta damai sebagaimana ditunjukkan tokoh Hatta sangat diperlukan dalam kehidupan seharihari, baik dalam lingkup keluarga maupun masyarakat luas. Sikap cinta damai akan menumbuhkan perilaku yang mengedepankan jalinan kerukunan dan kenyamanan dalam berinteraksi sebagai salah satu upaya nyata menghindari perselisihan dan permusuhan (Setyawan, Suwandi, \& Slamet, 2017).

\section{Karakter Gemar Membaca}

Gemar membaca yakni kebiasaan dengan tanpa paksaan untuk menyediakan waktu secara khusus guna membaca berbagai informasi, baik buku, jurnal, majalah dan koran sehingga menimbulkan kebijakan bagi dirinya (Kemendiknas, 2011). Gemar artinya suka, senang sekali. Gemar membaca dapat diartikan sebagai kesukaan akan membaca, ada kecenderungan hati ingin membaca.

Berdasarkan Undang-Undang Nomor 43 tahun 2007, tentang Perpustakaan bahwa budaya gemar membaca menjadi tanggung jawab keluarga, satuan pendidikan (sekolah), masyarakat, maupun pemerintah. Undang-undang tentang perpustakaan 
pasal 48 menegaskan hal-hal berikut. Pertama, pembudayaan kegemaran membaca dilakukan melalui keluarga, satuan pendidikan, dan masyarakat. Kedua, pembudayaan kegemaran membaca pada keluarga difasilitasi oleh Pemerintah Pusat dan Pemerintah Daerah melalui buku murah dan berkualitas. Ketiga, pembudayaan kegemaran membaca pada satuan pendidikan dilakukan dengan mengembangkan dan memanfaatkan perpustakaan sebagai proses pembelajaran. Keempat, pembudayaan kegemaran membaca pada masyarakat dilakukan melalui penyediaan sarana perpustakaan di tempat-tempat umum yang mudah dijangkau, murah, dan bermutu (Kemenkumham, 2007).

Sosok Hatta patut dicontoh dalam hal karakter gemar membaca. Dalam segala kesempatan, buku menjadi hal utama dalam keseharian kehidupan Hatta. Bahkan, saat dalam penjara pun, buku-buku yang menemani Hatta menghabiskan waktu dalam kungkungan fisik tembok penjara atau tempat-tempat pengasingan.

Sesaat sebelum Mr. Duys pamit, Hatta sempat melirik sipir penjara yang masih berdiri kaku di samping pintu sel. Dia berbisik pelan ke telinga Mr. Duys, "Kalau Tuan tidak keberatan, bisakah kiranya saya dikirimi beberapa buku mengenai hukum konstitusi dan ilmu politik?" "Buku-buku apakah itu?" tanya Mr. Duys hati-hati. Terutama buku-buku Kranemburg dn Krabbe, dan satu set lengkap majalah Indonesia Merdeka, jika memungkinkan, guna membantu menyusun pembelaanku (hlm 105).
Pada saat akan diasingkan ke Boven Digul oleh Pemerintahan Kolonial Belanda, yang terpikirkan pertama kali dalam benak Hatta adalah buku. Bagi Hatta, hidup akan terasa hampa tanpa buku.

Ini adalah hari kedua Hatta berada di rumah kakaknya di Jalan Kebon Jeruk. Pemerintah Belanda memberikan izin tiga hari kepadanya, untuk mengemas buku-buku yang akan dibawa, setelah keluar pernyataan resmi dia akan diasingkan ke Digul. Di kamar, dia masih disibukkan dengan urusan mengemas bukubuku ke dalam peti besi, dibantu oleh tiga kemenakannya. Ratusan buku inilah kelak yang akan menemani hari-harinya di pembuangan Digul. Semua kenangan tentang buku-buku berseliweran laiknya kunangkunang yang beterbangan. Apa jadinya hidup ini bila tak ada buku? Dia meneliti masingmasing peti (hlm 178).

Buku adalah segala-galanya dalam perjalanan hidup Hatta. Oleh karena itulah, dalam penataan rumahnya, hal terpenting harus mendapat tempat terbaik adalah bukubuku koleksinya. Kutipan berikut ini menegaskan fakta tersebut.

Dipandanginya ribuan buku yang tersusun rapi di sebuah rak panjang bersusun. Buku-buku yang sudah membuktikan kesetiaan, menemani tahun-tahun panjangnya hingga hari ini. Tapi, seperti baru kemarin saja. Dia melangkah ke sisi kiri rak dekat pintu masuk. Ditatapnya deretan buku itu. Sebagian didapat dari De Westerboekhandel, toko buku langganannya di Rotterdam. Sebagian lagi kubeli saat aku di Leiden, Paris, Brussel, dan Swiss. 
Sewaktu berada di pembuangan Banda Neira, ada juga yang kupesan dari toko buku Martinies-Nijhoff di Den Hag. Kubeli dengan uang honor menulis selama masa pembuangan. Adapula yang didapatnya di Hamburg saat inflasi Jerman 1921. Dia ingat sekali, kala itu dia nyaris seperti orang kalap memborong puluhan buku. Karena inflasi, gulden yang dibawa melonjak tinggi, hingga buku-buku itu menjadi murah harganya. Buku-buku itu tidak kujualbelikan. Dia menjadi milikku selamanya. Ini buktinya. Mereka bertakhta aman bersamaku kini (hlm 21).

Hatta dan buku adalah
gambaran nyata aktivitas dan kegemaran membaca. Kecintaan pada buku yang dapat dikatakan sangat berlebihan dalam diri Hatta salah satunya ditunjukkan melalui peristiwa penting dalam hidupnya. Saat menikah dengan Rahmi binti Rachim, Hatta memilih sebuah buku berjudul Alam Pikiran Yunani sebagai maskawin. Hal itu tentu saja dianggap sesuatu yang aneh dan tidak lazim, bahkan bagi ibu kandungnya. Siti Saleha, ibu kandungnya, sudah berkali-kali membujuk untuk menyertakan pecahan emas, sebagai mahar pernikahan. Bagi Hatta, buku lebih bernilai daripada uang dan emas.

Mahar kawin sebuah buku yang ditulis sendiri oleh Hatta saat di Digul seakan membuka lembar baru hidupnya, sekaligus membawanya pada pelajaran pertama tentang kekerasan prinsip yang dimiliki sang suami. Dia mendengarnya semalam sebelum pernikahan mereka. "Onde ... Atta, apa kata orang-orang nanti?” itu yang disampaikan Siti Saleha saat mengetahui mahar kawin anaknya. "Orang Minang selalu memberikan mahar kawin berupa uang dan emas. Apa kata orang nanti? Mamak juga ada uang emas untuk mahar kawinmu" (hlm 303).

Di rumah yang ditinggali bersama keluarga setelah menyatakan mundur sebagai Wakil Presiden, Hatta menjadikan buku-buku sebagai harta miliknya yang paling istimewa. Di lantai dua rumah itu, sekeliling mata memandang, selalu tampak buku. Buku adalah kawan setianya, kawan sepenanggungan yang menyimpan banak rahasia dan cinta. Sebagian alasannya meninggalkan kemegahan Istana Merdeka pun, sesungguhnya ada dalam ribuan buku di kamar ini. Bukan alasan emosional, karena buku-buku itu telah mengajarkan banyak kebenaran (Sutanto, 2018).

\section{Karakter Kejujuran}

Jujur yakni sikap dan perilaku yang menceminkan kesatuan antara pengetahuan, perkataan dan perbuatan (mengetahui apa yang benar, mengatakan yang benar dan melakukan yang benar) sehingga menjadikan orang yang bersangkutan sebagai pribadi yang dapat dipercaya (Kemendiknas, 2011). Jika seseorang berkata tidak sesuai dengan kebenaran dan kenyataan atau tidak mengakui suatu hal sesuai dengan apa adanya, maka orang tersebut dapat dianggap atau dinilai tidak jujur, menipu, mungkir, berbohong, munafik dan sebagainya. Jadi jujur adalah suatu karakter yang berarti berani menyatakan keyakinan pribadi, menunjukkan siapa dirinya.

Kejujuran tercermin dalam prilaku yang diikuti dengan hati yang 
lurus (ikhlas), berbicara sesuai dengan kenyataan, berbuat sesuai bukti dan kebenaran. Dengan demikian kejujuran merupakan salah satu unsur kekuatan spiritual, akhlak mulia, serta kepribadian. Jujur adalah sebuah prilaku manusia yang mempunyai definisi transparan, tidak ada yang ditutupi sebagai penghilang sebuah tingkah laku atau alasan kita kepada orang lain (Aziz, 2011).

Nilai kejujuran dalam diri tokoh Hatta tampak saat ia dan kawan-kawan pergerakkan ditangkap Pemerintah Belanda karena dituduh melakukan pemberontakan dan penghasutan. Hatta dan kawan-kawan ditahan Pemerintah Belanda dengan alasan akan melarikan diri.

"Kami terlalu jantan untuk lari. Kami berjuang untuk suatu citacita tinggi dan lari hanya merusak tujuan kami sendiri". "Lari adalah suatu perbuatan pengecut yang tak mungkin akan kami lakukan". "Sekiranya ada niat saya lari," kata Hatta lagi, "Justru Nederland tak akan pernah dapat menangkap saya yang sedang di Swiss sewaktu rumah-rumah kami di geledah. Kejujuran melarang lami menjadi orang pengecut. Walau akhirnya kejujuran kami dibayar dengan kurungan lima setengah bulan dalam penjara" (hlm 126).

Sifat kejujuran pula yang menuntun Hatta mengambil pilihan dan keputusan yang besar, yakni mengundurkan diri dari posisinya sebagai Wakil Presiden. Satu hal yang dianggap Hatta sangat mendasar sampai akhirnya memutuskan mundur dari jabatan. Dia enggan menjadi penonton sirkus yang dipaksa bersorak usai pentas, padahal pentas itu sama sekali tidak menyenangkan hati.
Bukan pula sekadar soal korupsi yang mulai mengganas seperti singa muda lapar. Entah seperti apa rupa negeri ini. Uang rakyat habis dihambur-hamburkan rombongan besar petinggi negara beserta wartawan yang melawat ke luar negeri. Bak sirkus mereka berkeliling menjemput sorak sorai. Lawatan yang akhirnya malah menjadi hobi, sekadar pesta pora memabukkan dan alpa dari masksud semula: diplomasi. Revolusi sudah berakhir. Dwitunggal yang tidak mempunyai kekuasaan tidak ada gunanya (hlm 18-19).

Dalam diri Hatta bergolak antara kejujuran nurani dan mengikuti pemerintahan yang sudah mulai menyeleweng dari cita-cita luhur perjuangan kemerdekaan. Hatta memilih hidup menjadi rakyat biasa dengan kesederhanaan dan kejujuran.

"Hatta terpekur di atas sajadah biru tua. Dia baru selesai shalat Magrib. Terlintas kenangan pergumulan batinnya tatkala dia harus mengambil keputusan: mundur dari jabatan dan meninggalkan Soekarno dengan segala keinginan. Bagi Hatta, menjadi rakyat biasa adalah sebuah pilihan yang tepat. Tidak ada gunanya memangku jabatan bila suara terkunci dalam labirin kemelut yang tidak berujung. Semoga ke depan, langkah pemerintahan semakin cakap dan memiliki kewibawaan. Itulah harapan Hatta kini" (hlm 279).

Setelah mengundurkan diri dari jabatan wakil presiden, Hatta memilih mengabdikan ilmu yang dimiliki dengan menjadi dosen di Universitas Gadjah Mada Yogyakarta. Mengajar dan mendidik bagi Hatta bagaikan 
nafas. Kini sebagian besar waktunya diberikan untuk mengajar di Fakultas Ekonomi dan Sosial Politik. Perjalanan kehidupan Hatta ternyata tidak selalu lurus dan mulus. Sikap dan karakter kejujurannya, kini diuji kembali. Pada akhir tahun 1960, Hatta diberhentikan dan tidak boleh mengajar lagi di UGM karena dianggap pemikirannya berseberangan dengan kebijakan Demokrasi Terpimpin. Hatta menerima keputusan mengejutkan itu dengan keyakinan bahwa dirinya kini telah terbebas dari beban menjadi kepanjangan tangan kebijakan pemerintah yang dianggap salah (hlm 283).

Dalam diri Hatta tertanam keyakinan akan kebenaran yang selama ini telah diperjuangkan. Sudah lama ia menempa diri dengan mengambil resiko untuk sebuah paham yang diyakini kebenarannya. Tempat-tempat bersejarah dalam hidupnya, seperti Boven Digul, Banda Neira, Penjara Glodok, Penjara di Negeri Belanda, Pulau Bangka menjadi saksi catatan atas keteguhan prinsip hidupnya (hlm 285). Bagi Hatta, sebuah kebenaran memang mahal harganya, apalagi jika dijahit dengan benang kejujuran. Sama sekali tidak ada tawar menawar di dalamnya (hlm 284).

Kata kunci etika dan moralitas adalah kejujuran (Aziz, 2011). Jujur untuk mengungkapkan apa adanya tanpa harus menutupinya oleh alasan apapun, termasuk alasan dan ketakutan akan rasa malu karena harus menanggung resiko dari kejujuran. Seorang ahli hikmah mengatakan: "perkataan orang berakal bermula dari hatinya, sedang perkataan orang yang jahil berawal dari lisannya dan berbicara sesuka hatinya".
Hatta memegang teguh prinsip kejujuran dalam menjalani kehidupan. Keadaan yang memaksa dan keinginan memenuhi kebutuhan orang-orang yang dicintai tidak harus mengorbankan nilai kejujuran. Meskipun dalam kondisi kehidupan yang pas-pasan, bahkan agak kekurangan, Hatta tidak memanfaatkan kesempatan demi keuntungan diri dan keluarganya. Tawaran-tawaran yang mengiurkan selalu ditolak karena Hatta merasa tawaran itu dapat meruntuhkan prinsip kejujuran.

"Suatu sore, Hatta menerima tamu. Sudah lima belas menit lebih mereka mengobrol. "Bagaimana Bung Hatta?" "Saya mengucapkan terima kasih atas tawaran Saudara. Tapi, maaf saya tidak bisa menerimanya". Tak lama, tamu pun pamit. Bukan hal yang aneh. Tamu-tamu yang datang menawarkan posisi pada Hatta selalu pulang dengan penolakan halus. Bukan sekali pula Rahmi mendapat jawaban klasik, "Yuke, kalau kuterima jabatan itu, apa kata rakyat nanti', setiap dia bertanya. "Mengapa ditolak". Ayah ditawari menjadi komisaris salah satu perusahaan asing, ya, Bu?" tanya anak tertuanya, Meutia. "Ya. Tapi Seperti biasanya, ayahmu menolak" (hlm 306).

Kejujuran sering diibaratkan sebagai mata uang yang akan berlaku di manapun dan tidak terbatasi oleh ruang, wilayah, negara bahkan oleh waktu. Kejujuran sama halnya kebenaran acap kali sering terdesak oleh kuatnya ambisi kekuasaan dan pengaruh duniawi. Hal yang harus diyakini bahwa kejujuran dan kebenaran itu tidak akan pernah dapat dimusnahkan. Bahkan, orang yang berbuat salah dan dosa sekalipun akan dianggap benar, karena 
kejujurannya mau mengakui semua kesalahan yang diperbuat (Azis, 2011).

\section{Pola Pengekpresian Nilai Karakter. Penyampaian Nilai Karakter Secara Langsung}

Penyampaian nilai karakter secara langsung dilakukan dengan cara pendeskrip-sian karakter dan perilaku atau tindakan tokoh secara terperinci oleh pengarang (pencerita). Melalui deskripsi pengarang pembaca dapat mengidentifikasi pola pikir, tindakan, dan sikap tokoh. Pola pikir, tindakan, dan sikap tokoh itulah yang pada akhirnya bermuara pada karakteristik pribadi dan karakter yang dimiliki tokoh tersebut (Nurgiyantoro, 2015).

Karakter dalam diri Hatta yang digambarkan secara terperinci dan berulang-ulang oleh pengarang adalah nilai karakter gemar membaca. Deskripsi tentang buku, perpustakaan dan aktivitas membaca yang dilakukan oleh sosok Hatta diceritakan dan digambarkan secara jelas dan berulangulang sesuai dengan konteks dan situasinya.

$\begin{array}{ccc}\text { Pengarang } & \text { berusaha } \\ \text { menggambarkan } & \text { secara langsung }\end{array}$ hubungan istimewa Hatta dengan bukubukunya. Melalui deskripsi tersebut pengarang ingin menyampaikan pesan moral bagi pembaca untuk meneladani sikap dan karakter tokoh Hatta sebagai sosok yang lekat dengan buku dan aktivitas membaca, di mana pun dan kapan pun ia berada.

Buku dan aktivitas membaca dicerikan dari awal sampai akhir dalam novel biografi Hatta. Gambaran tokoh dan tindakannya yang menjadi penanda nilai karakter gemar membaca, antara lain: (a) menggunakan sebagian besar uang beasiswa untuk membeli buku, (b) kebiasaan merawat dan menyimpan buku, (c) perpustakaan atau ruang khusus untuk buku di mana pun ia sedang tinggal, (d) buku menjadi barang pokok saat berada dalam penjara atau di pengasingan, dan (e) buku menjadi mahar atau mas kawin dalam prosesi pernikahan.

Pengarang seolah-olah ingin memberikan doktrin atau nasehat secara langsung kepada para pembaca tentang pentingnya kebiasaan dan kegemaran membaca buku. Pengarang menaruh harapan besar agar nilai karakter itu dapat diteladani oleh para pembaca. Hal itu tampaknya masih memiliki relevansi dengan kondisi sekarang ini, khususnya bagi generasi membaca.

Fakta menunjukkan bahwa kebiasaan membaca masyarakat Indonesia masih tergolong rendah. Hasil survei UNESCO pada 2011, indeks tingkat membaca masyarakat Indonesia hanya 0,001 persen. Hasil penelitian Programme for International Student Assessment (PISA), budaya literasi masyarakat Indonesia pada tahun 2012 terburuk kedua dari 65 negara yang diteliti di dunia. Data World's Most Literate Nations, yang disusun oleh Central Connecticut State University tahun 2016, peringkat literasi Indonesia berada di posisi kedua terbawah dari 61 negara yang diteliti (Suryaman, 2015).

\section{Penyampaian Nilai Karakter Secara Tidak Langsung}

Penyampaian nilai karakter secara tidak langsung dilakukan melalui rangkaian peristiwa dan konflik yang dialami tokoh. Dengan demikian, sebagaimana halnya pada deskripsi tokoh, melalui paparan peristiwa dan konflik pembaca juga dapat menemukan pesan tersembunyi 
berkaitan dengan moral dan karakter tokoh (Nurgiyantoro, 2015).

Nilai karakter kemandirian disajikan melalui serangkaian peristiwa dan konflik yang dialami tokoh Hatta. Beberapa peristiwa yang menyiratkan nilai karakter kemandirian, antara lain: (a) saat menempuh dan menjalani pendidikan sejak di Bukit Tinggi, Padang, Betawi (Jakarta), dan Negeri Belanda, (b) aktif dalam kegiatan Perhimpoenan Indonesia saat di Negeri Belanda, (c) menyusun sendiri naskah pembelaan saat pengadilan di Negeri Belanda, dan (d) menjalani kehidupan saat di penjara dan di pengasingan.

Nilai karakter semangat kebangsaan dalam diri Hatta dapat dipahami pembaca melalui serangkaian peristiwa dan konflik yang menggambarkan kegigihannya memperjuangkan kemerdekaan Indonesia. Semangat kebangsaan dalam diri Hatta disampaikan oleh pengarang melalui beberapa peristiwa: (a) aktivitas di organisai Perhimpoenan Indonesia saat menempuh studi di Negeri Belanda, (b) menulis dan membuat majalah dan buku untuk menyebarluaskan semangat kemerdekaan Indonesia, (c) terlibat aktif dalam pergerakan dan perjuangan kemerdekaan Indonesia, mempersiapkan proklamasi kemerdekaan Indonesia, dan (e) memproklamasikan kemerdekaan Indonesia bersama Soekarno.

Pengarang menghadirkan karakter cinta tanah air dengan menyajikan peristiwa keputusan Hatta untuk pulang ke Indonesia dan melanjutkan perjuangan dan pembangunan untuk tanah air Indonesia. Sesudah melewati berbagai romantika perjuangan di Negeri Belanda, Hatta kembali ke Indonesia.
Sesungguhnya kalau mau, tokoh kelahiran Bukit Tinggi ini bisa hidup senang di Hindia Belanda karena dengan ilmu yang dimilikinya ia dapat mengabdi pada Pemerintah Kolonial Belanda. Tetapi Hatta tidak memilih berjalan "di bawah sinar rembulan". Ia tetap terus berjuang untuk kemerdekaan tanah airnya.

Karakter cinta damai disajikan oleh pengarang melalui peristiwa kunjungan Hatta menjenguk Soekarno yang sakit dan dirawat di RSPAD. Hatta tidak menyimpan dendam meskipun pernah mengalami masamasa sulit dan perlakuan yang tidak adil dari pemerintahan Soekarno. Itulah babak terpenting dalam hidup Hatta, saat ia harus mengurai kembali sejarah luka sekaligus menutupnya dengan sebuah kata maaf untuk Soekarno. Hatta meyakini bahwa seringkali penderitaan yang dijalani dengan ketabahan akan berubah menjadi sebuah keberanian untuk terus hidup dan memaafkan (hlm 352).

Karakter kejujuran disajikan oleh pengarang melalui peristiwa dan konflik yang dialami Hatta dalam kehidupannya setelah mengundurkan diri dari jabatan waklil presiden. Hatta memegang teguh prinsip kejujuran dalam menjalani kehidupan. Keadaan yang memaksa dan keinginan memenuhi kebutuhan orang-orang yang dicintai tidak harus mengorbankan nilai kejujuran. Meskipun mengalami kesulitan ekonomi, Hatta tidak memanfaatkan kesempatan demi keuntungan diri dan keluarganya. Tawaran-tawaran yang mengiurkan untuk menduduki jabatan yang menguntungkan secara finansial, selalu ditolak karena Hatta merasa tawaran itu dapat meruntuhkan prinsip kejujuran (Azis, 2011). 


\section{PENUTUP}

Berdasarkan hasil dan pembahasan, simpulan penelitian sebagai berikut. Pertama, terdapat enam nilai karakter utama dalam novel biografi Mohammad Hatta, yaitu (a) karakter mandiri, dengan indikator sejak kecil tinggal terpisah dari orang tua untuk menempuh pendidikan; (b) karakter semangat kebangsaan (nasional), dengan terlibat aktif dalam pergerakan dan perjuangan merebut kemerdekaan negara Indonesia; (c) karakter cinta tanah air, dengan memutuskan kembali ke tanah air meskipun ada kesempatan yang lebih bagus di luar negeri; (d) karakter cinta damai, dengan menjaga dan memelihara persahabatan dengan pihak atau orang yang memusuhi dan membenci; (e) karakter gemar membaca, dengan menjadikan buku sebagai bagian penting dalam sejarah perjalanan hidup, dan (f) karakter kejujuran, sikap dan perilaku yang menceminkan kesatuan antara pengetahuan, perkataan, dan perbuatan sebagai pribadi yang dapat dipercaya. Kedua, terdapat dua pola pengekspresian dan penyampaian nilainilai karakter, yakni (a) penyampaian langsung, melalui deskripsi langsung pengarang tentang karakter, perilaku, dan tindakan tokoh; dan (b) penyampaian tidak langsung, melalui paparan sikap dan tingkah laku tokoh menghadapi peristiwa dan konflik. Nilai karakter yang dominan disajikan dalam novel biografi Hatta adalah karakter gemar membaca dan sebagian besar nilai-nilai karakter tersebut disampaikan dengan cara tidak langsung.

Sehubungan dengan temuan penelitian ini, dikemukakan saran-saran sebagai berikut. Pertama, sumber data pada penelitian ini masih terbatas pada novel biografi dari tokoh yang berpengaruh dan pejabat tinggi pemerintahan. Untuk itu, masih terbuka luas untuk meneliti novel-novel biografi yang ditulis berdasarkan tokohtokoh yang berasal dari berbagai bidang kehidupan. Harapannya, akan diperoleh deskripsi nilai-nilai karakter yang beragam. Kedua, novel biografi dapat digunakan sebagai bahan ajar pembelajaran sastra di sekolah, utamanya diarahkan untuk membantu upaya pengembangan karakter dan kepribadian siswa (Kasiyan, 2002). Cerita biografi dapat menjadi sarana efektif mengingatkan kembali narasi publik terhadap sosok tokoh yang penuh dengan keteladanan (Thomas, 2019). Ketiga, pemilihan novel biografi sebagai bahan pembelajaran sastra harus tetap mempertimbangkan aspek sosio-budaya, perkembangan kognisi dan bahasa, dan psikologis siswa.

\section{UCAPAN TERIMA KASIH}

Ucapan terima kasih disampaikan kepada Dr. Nurhadi, M.Hum., teman sejawat yang berkenan memberikan masukan dan saran dalam kegiatan pemilahan, pemilihan, dan penafsiran data untuk menentukan nilai dan cara pengekspresian karakter dalam proses penelitian. Ucapan terima kasih juga disampaikan kepada Redaktur Jurnal Pendidikan Karakter atas saran dan masukan untuk perbaikan artikel ini.

\section{DAFTAR PUSTAKA}

Abrams, M.H. (2000). Glosary of literary terms (Seventh Edition). Wardsworth Publishi Company. 
Azizah, D. F. \& Marzuki. (2018). Kandungan nilai-nilai karakter kewargaan dalam novel Pulang karya Darwis Tere Liye. Jurnal Pendidikan Karakter. 8(2), 114122.

DOI: https://doi.org/10.21831/jp k.v8i2.21271.

Aziz, H. A. (2011). Pendidikan karakter berpusat pada hati. Jakarta: Penerbit Al-Mawardi Prima.

Hasan, F. (2002). Catatan perihal sastra dan pendidikan. Dalam Warta HISKI Desember 2002.

Kasiyan. (2002). Pendidikan kesenian dalam pembangunan karakter bangsa. Jurnal Cakrawala Pendidikan. 21(1), 33-55. DOI: https://doi.org/10.21831/cp. v1i1.7465.

Kemendiknas. (2010). Pengembangan pendidikan budaya dan karakter bangsa. Jakarta: Badan Penelitian dan Pengembangan Pusat Kurikulum.

Kemendiknas. (2011). Panduan pelaksanaan pendidikan karakter. Jakarta: Badan Penelitian dan Pengembangan Pusat Kurikulum dan Perbukuan.

Kemenkumham. (2007). UndangUndang Nomor 43 Tahun 2007, tentang Perpustakaan. Jakarta: Sekretariat Negara.

Khofiyana, E., Suyitno, \& Saddhono, K. (2013). Pengembangan bahan ajar membaca biografi di SMA melalui analisis novel biografi Sepatu Dahlan. BASASTRA Jurnal Penelitian Bahasa, Sastra Indonesia dan Pengajarannya. 1(3), $\quad$ 448-462. http://jurnal.fkip.uns.ac.id/index.p $\mathrm{hp} / \mathrm{bhs}$ indonesia/article/view/40 43/2842.
Kleden, I. (2004). Sastra Indonesia dalam enam pertanyaan: esaiesai sastra dan budaya. Jakarta: Pustaka Utama Grafiti.

Lickona, T. (1993). The return of character education. New York: Educational Leadership.

Mustopo, M. H. (1983). Pendidikan sejarah perjuangan bangsa. Jakarta: Badan Penelitian dan Pengembangan Pendidikan dan Kebudayaan.

Nurgiyantoro, B. (2015). Teori pengkajian fiksi. Yogyakarta: Gajah Mada University

Refly, H. Z. (1993). Nasionalisme, universalisme, dan struktur kesadaran. Makalah dalam Panel Forum Indonesia Pasca-Nasional diselenggarakan di Universitas Gadjah Mada, 21-22 April 1993.

Rostiyati, Khuzaemah, E., \& Mulyaningsih, I. (2019). Analisis nilai moral pada buku Buya Hamka sebuah novel biografi karya Haidar Musyafa. Jurnal Bindo Sastra. 3(1), 39-47. DOI: https://doi.org/10.32502/jbs .v3i1.1977.

Setyawan, A., Suwandi, S., \& Slamet, St. Y. (2017). Muatan pendidikan karakter dalam cerita rakyat di Pacitan. Jurnal Pendidikan Karakter. $\quad 7(2), \quad$ 199-211. DOI: https://doi.org/10.21831/jp k.v7i2.21778.

Smit, C. B. (2002). Developing character through literature: a teacher's resource book. Bloomington: ERIC Clearinghouse on Reading, English, and Communication.

Suryaman, M. (2015). Analisis hasil belajar peserta didik dalam literasi membaca melalui studi internasional (PIRLS) 2011. 
Jurnal Litera. 14(1), 170-186. DOI: https://doi.org/10.21831/ltr. v14i1.4416.

Sutanto, S. (2018). Hatta: aku datang karena sejarah. Edisi Kedua. Bandung: Penerbit Qanita.

Thomas, R. R. (2019). Call my name: using biographical storytelling to reconceptualize the history of African Americans at Clemson University. Journal Biography.
42(3), 624-652. DOI: 10.1353/bio.2019.0063.

Youpika, F. \& Zuchdi, D. (2016). Nilai pendidikan karakter cerita rakyat suku Pasemah Bengkulu dan relevansinya sebagai materi pembelajaran sastra. Jurnal Pendidikan Karakter. 6(1), 4858.

DOI: https://doi.org/10.21831/jp k.v0i1.10731. 